\title{
Thiol group modulation of sodium-lithium countertransport kinetics in diabetic nephropathy
}

\author{
S.C. J ones, T. H . Thomas, S. M . M arshall \\ Department of Medicine, University of Newcastle upon Tyne, Newcastle upon Tyne, UK
}

Summary Abnormal erythrocyte sodium-lithium countertransport (Na-Li CT) activity, traditionally measured at a single sodium concentration of $140 \mathrm{mmol} \cdot \mathrm{l}^{-1}\left(\mathrm{~V}_{140}\right)$, may represent an inherited risk marker for diabetic nephropathy. The membrane defect underlying this association is poorly understood, though modulation by key protein thiol groups appears to be important in essential hypertension. To improve understanding of this abnormality, $\mathrm{Na}-\mathrm{Li}$ CT kinetics in untreated erythrocytes and after thiol group alkylation with $\mathrm{N}$-ethylmaleimide were investigated in 18 subjects with diabetic nephropathy, 20 normoalbuminuric insulin-dependent diabetic (IDDM) subjects and 18 non-diabetic individuals. Using the traditional assay, $\mathrm{V}_{140}$ was similar in subjects with diabetic nephropathy compared to IDDM control subjects vs $0.311(0.152-0.475)$ (0.247 (0.111$0.498) \mathrm{mmol} \mathrm{Li} \cdot \mathrm{h}^{-1} \cdot 1$ erythrocytes $\left.{ }^{-1}\right)$. Kinetic parameters were abnormal in subjects with diabetic nephropathy compared with diabetic and non-diabetic control subjects, with both $\mathrm{V}_{\max }$ (maximal $\mathrm{Na}-\mathrm{Li}$ CT activity) (0.454 (0.257-0.963) vs 0.338 (0.183$0.972)$ vs $0.332(0.213-0.603) \mathrm{mmol} \mathrm{Li} \cdot \mathrm{h}^{-1} \cdot 1$ erythrocytes $\left.^{-1}, \mathrm{p}<0.05\right)$, and $\mathrm{V}_{\max } / \mathrm{K}_{\mathrm{m}}($ So $)$ ratio, reflecting ion association (6.03 (2.3-9.6) vs $4.73(2.0-10.4)$ vs 4.48 (1.5-7.1), $\mathrm{p}<0.01)$, significantly higher. N-ethylmaleimide decreased $\mathrm{K}_{\mathrm{m}}($ So $)$ and $\mathrm{V}_{\max }$ abolishing differences in $\mathrm{V}_{\max } / \mathrm{K}_{\mathrm{m}}(\mathrm{So})$ ratio between groups $(2.45$ (1.18-4.21) vs $2.23(0.96-4.3)$ vs $2.44(1.4-3.7)$, but enhancing the differences in $\mathrm{V}_{\max }(0.186(0.090-0.315)$ vs $0.120(0.051-0.256)$ vs $0.128(0.080-0.206) \mathrm{mmol}$ $\mathrm{Li} \cdot \mathrm{h}^{-1} \cdot 1$ erythrocytes $\left.{ }^{-1}, \mathrm{p}<0.0001\right)$. Of subjects with diabetic nephropathy, $78 \%$ were outside the 75th percentile of the non-diabetic control subjects when $\mathrm{V}_{\max }$ and $\mathrm{V}_{\max } / \mathrm{K}_{\mathrm{m}}($ So) ratio were combined, compared to $20 \%$ of the normoalbuminuric control subjects. We conclude that the traditional assay, $\mathrm{V}_{140}$, is poor at detecting individuals with diabetic nephropathy. Study of the kinetic parameters of the transporter, including thiol group modulation, suggests that increased ion association, $\mathrm{V}_{\max } / \mathrm{K}_{\mathrm{m}}(\mathrm{So})$ ratio may represent the inherited defect and improves identification of subjects with diabetic nephropathy. [Diabetologia (1997) 40: 1079-1084]

Keywords Diabetic nephropathy, sodium-lithium countertransport, thiol group, N-ethylmaleimide, erythrocyte, insulin-dependent diabetes mellitus.
Received: 17 January 1997 and in revised form: 5 May 1997

Corresponding author: Dr. S. C. Jones, Department of Medicine, The Medical School, Framlington Place, Newcastle Upon Tyne, NE2 4HH, UK

A bbreviations: IDDM, Insulin-dependent diabetes mellitus; $\mathrm{K}_{\mathrm{m}}(\mathrm{So})$, Michaelis constant for external sodium; Na-Li CT, sodium-lithium countertransport; NEM, N-ethylmaleimide; $\mathrm{V}_{\text {max }}$, maximal efflux of lithium across erythrocyte membrane, $\mathrm{V}_{140}$, Na-Li CT activity measured at a sodium concentration of $140 \mathrm{mmol}^{-1} \mathrm{Na}$; UAER, urinary albumin excretion rate; ACE, angiotensin converting enzyme.
Inherited factors [1], as well as poor glycaemic control [2], are important in the aetiology of diabetic kidney disease. Abnormal sodium-lithium countertransport (Na-Li CT) activity has been associated with diabetic nephropathy in a number of cross-sectional studies [3-6]. As Na-Li CT activity has a major inherited component [7] it has been suggested that a defect in this system could represent a useful inherited marker of those at increased risk of developing diabetic nephropathy. The traditional assay of Na-Li CT measures activity at a single sodium concentration of 
$140 \mathrm{mmol} \cdot \mathrm{l}^{-1}\left(\mathrm{~V}_{140}\right)$ and provides only limited information. This is because Na-Li CT obeys MichaelisMenten kinetics and $V_{140}$ is determined by the kinetic parameters $\mathrm{V}_{\max }$, maximal transporter activity and $\mathrm{K}_{\mathrm{m}}(\mathrm{So})$, the Michaelis constant for external sodium. $\mathrm{K}_{\mathrm{m}}(\mathrm{So})$ is a complex composite of rate constants [8] and the $\mathrm{V}_{\text {max }} / \mathrm{K}_{\mathrm{m}}$ (So) ratio represents a much simpler measure of ion association, sometimes called the "minimum ion association rate constant". The traditional Na-Li CT assay may fail to detect changes in kinetic parameters, as disease states may bring about changes in both ion association and $\mathrm{V}_{\max }$ in such a way as to leave $\mathrm{V}_{140}$ unaffected.

Na-Li CT activity is modulated by key protein thiol groups $[9,10,11]$. When these thiol groups are alkylated by N-ethylmaleimide (NEM), the increased $\mathrm{V}_{\max } / \mathrm{K}_{\mathrm{m}}(\mathrm{So})$ ratio in subjects with essential hypertension is abolished [12], suggesting that abnormal thiol group activity is responsible for this potentially inherited defect. The detection of such a defect in subjects with diabetic nephropathy may allow clearer definition of the membrane defect specific for this condition.

The ability of Na-Li CT, assessed using $\mathrm{V}_{140}$, to discriminate between individuals with diabetic nephropathy and control subjects has been poor, with overlap as great as $80 \%$ in some studies [5,6]. A study in which the kinetic defect underlying abnormal Na-Li CT activity is approached, and in which subjects are carefully selected to avoid confounding factors such as uraemia and short diabetes duration, may be expected to improve the ability of this assay to discriminate between individuals with and without diabetic kidney disease.

The aims of this study were therefore to improve our understanding of abnormal Na-Li CT kinetic parameters in diabetic nephropathy and secondly to investigate if this enhanced understanding of the underlying defect, together with better subject selection, improves our ability to identify correctly individuals with and without diabetic nephropathy.

\section{Subjects and methods}

Patients. Eighteen patients with insulin-dependent diabetes mellitus (IDDM) (initial presentation with weight loss and ketosis, at under 35 years of age) and diabetic nephropathy were studied. A median urinary albumin excretion rate (UAER) from three timed overnight collections of greater than $20 \mu \mathrm{g}$. $\mathrm{min}^{-1}$ (inter-assay coefficient of variation at $4.95 \mathrm{mg} \cdot \mathrm{l}^{-1}$, $3.6 \%$ ) was used to define the presence of diabetic nephropathy. Subjects with a UAER in the microalbuminuric range $\left(20-200 \mu \mathrm{g} \cdot \mathrm{min}^{-1}\right)$ were only included if the median of a further three collections, within 3-6 months, confirmed the presence of raised UAER. Patients were excluded if serum creatinine exceeded $150 \mu \mathrm{mol} \cdot \mathrm{l}^{-1}$ to avoid confounding effects of uraemia on Na-Li CT activity. A control group of 20 subjects with IDDM and normal UAER (less than $20 \mu \mathrm{g} \cdot \mathrm{min}^{-1}$ ) of similar age and sex to the subjects with diabetic nephropathy was studied. To ensure that they were unlikely to develop nephropathy in the future, duration of diabetes was greater than 20 years. A second control group of 18 non-diabetic subjects was also studied. These individuals had no personal history of, nor first-degree relative with either IDDM or non-insulin-dependent diabetes (NIDDM), hypertension or dyslipidaemia. Nine of the subjects with IDDM and nephropathy were taking an ACE inhibitor, four in combination with a diuretic. A further three subjects received a calcium channel blocking agent and two received lipid-lowering drugs. One control subject with IDDM was taking a calcium channel blocking agent for hypertension but none of the non-diabetic control subjects were taking any medication. Ethical approval for this study was granted by the Newcastle Health Authority/Newcastle University Joint Ethical Committee, and all subjects gave their informed consent.

E valuation of subjects. Blood pressure (Korotkoff phases 1 and 5) was measured in the sitting position after $10 \mathrm{~min}$ rest, the values presented being the means of three recordings taken over a 10-min period. Retinopathy was recorded as present or absent on fundoscopy through dilated pupils. Isotopic glomerular filtration rate was measured with ${ }^{51} \mathrm{Cr}$ EDTA using a "single shot" method [13]. A two-compartment model was used to analyse the data. All blood samples were taken after an overnight fast of at least $10 \mathrm{~h}$. All medication, other than insulin, was stopped for the $24 \mathrm{~h}$ preceding the study. Glycated haemoglobin was assessed using an immuno-assay method (Tinaquant, Boehringer, Lewes, UK, normal range up to $5.2 \%$ ). Fasting serum triglycerides, total cholesterol and creatinine were determined using enzymatic methods (Hitachi 717 autoanalyser, Boehringer).

A ssay for the determination of standard Na-L i CT activity and its kinetic characteristics. The details of the assay used to measure $\mathrm{V}_{140}, \mathrm{~K}_{\mathrm{m}}(\mathrm{So})$ and $\mathrm{V}_{\max }$ are fully described in our previous reports $[6,12]$. Briefly Na-Li CT activity was measured as sodium-stimulated lithium efflux from washed, lithium loaded erythrocytes (internal lithium concentration 8 (7-9) $\mathrm{mmol} \cdot \mathrm{l}^{-1}$ ). Erythrocytes were incubated for up to $90 \mathrm{~min}$ at $37^{\circ} \mathrm{C}$ in choline medium and a range of sodium concentrations $(20,37.5$, $75,100,150 \mathrm{mmol} \cdot \mathrm{l}^{-1}$ ), with choline adjusted to maintain osmolarity. Na-Li CT activity was determined as the difference between lithium efflux from erythrocytes in the sodium and choline media. The Eadie-Hofstee transformation was used to calculate $\mathrm{K}_{\mathrm{m}}(\mathrm{So})$ and $\mathrm{V}_{\max }$.

NE M treatment of erythrocytes. Thiol group alkylation was effected by the addition of NEM $\left(4.5 \mu \mathrm{mol} \cdot \mathrm{ml}^{-1}\right.$ cells $)$ to erythrocytes suspended in sodium medium (14\% packed cell volume) and incubated for $100 \mathrm{~s}$. The reaction was stopped by the addition of mercaptoethanol $(50 \mu \mathrm{mol} / \mathrm{ml}$ erythrocytes $)$. The cells were then washed with choline medium and $V_{\max }$, $\mathrm{K}_{\mathrm{m}}(\mathrm{So})$ and $\mathrm{V}_{140}$ determined as above.

Statistical analysis. Analysis of variance (ANOVA) was used to test for differences between the three groups. If significant differences were found, Student's t-test (unpaired) was used for comparison between individual groups with correction for multiple testing. Data that are not normally distributed, including $\mathrm{V}_{\max }, \mathrm{K}_{\mathrm{m}}(\mathrm{So})$ and $\mathrm{V}_{140}$ were analysed with the Kruskall-Wallis test of variance and Mann-Whitney test. $\mathrm{V}_{\max }, \mathrm{V}_{\max } /$ $\mathrm{K}_{\mathrm{m}}(\mathrm{So})$ ratio and serum triglycerides were log transformed before regression analyses were carried out. 
Table 1. Clinical characteristics of subjects

\begin{tabular}{|c|c|c|c|}
\hline & $\begin{array}{l}\text { Normal } \\
\text { control } \\
\text { subjects } \\
(n=18)\end{array}$ & $\begin{array}{l}\text { IDDM } \\
\text { control } \\
\text { subjects } \\
(n=20)\end{array}$ & $\begin{array}{l}\text { Subjects with } \\
\text { IDDM and } \\
\text { nephropathy } \\
(\mathrm{n}=18)\end{array}$ \\
\hline $\begin{array}{l}\text { Age } \\
\text { (years) }\end{array}$ & $\begin{array}{l}40.2 \\
(36.7-43.7)\end{array}$ & $\begin{array}{l}44.3 \\
(40.7-47.9)\end{array}$ & $\begin{array}{l}43.2 \\
(38.4-48.0)\end{array}$ \\
\hline Sex (Male : Female) & $8: 10$ & $13: 7$ & $12: 6$ \\
\hline $\begin{array}{l}\text { Duration of IDDM } \\
\text { (years) }\end{array}$ & - & $\begin{array}{l}31.2 \\
(27.8-34.8)\end{array}$ & $\begin{array}{l}23.4^{\mathrm{a}} \\
(20.6-28.2)\end{array}$ \\
\hline $\begin{array}{l}\text { Body mass index } \\
\left(\mathrm{kg} \cdot \mathrm{m}^{-2}\right)\end{array}$ & $\begin{array}{l}23.2 \\
(21.8-24.6)\end{array}$ & $\begin{array}{l}25.0 \\
(24.4-25.6)\end{array}$ & $\begin{array}{l}27.0^{\mathrm{b}} \\
(25.8-28.2)\end{array}$ \\
\hline $\begin{array}{l}\text { Retinopathy } \\
\text { (Present : absent) }\end{array}$ & - & $7: 13$ & $16: 2^{\mathrm{a}}$ \\
\hline $\begin{array}{l}\text { Hypertension } \\
\text { (Present : absent) }\end{array}$ & $0: 18$ & $1: 19$ & $12: 6^{\mathrm{b}}$ \\
\hline $\begin{array}{l}\text { Systolic blood } \\
\text { pressure } \\
(\mathrm{mm} \mathrm{Hg})\end{array}$ & $\begin{array}{l}116 \\
(108-124)\end{array}$ & $\begin{array}{l}129 \\
(121-137)\end{array}$ & $\begin{array}{l}143^{\mathrm{c}} \\
(114-154)\end{array}$ \\
\hline $\begin{array}{l}\text { Diastolic blood } \\
\text { pressure } \\
(\mathrm{mm} \mathrm{Hg})\end{array}$ & $\begin{array}{l}73 \\
(67-79)\end{array}$ & $\begin{array}{l}76 \\
(72-80)\end{array}$ & $\begin{array}{l}85^{\mathrm{b}} \\
(81-89)\end{array}$ \\
\hline
\end{tabular}

Continuous variables described as means (95\% confidence intervals)

${ }^{a} p<0.05$, subjects with diabetic nephropathy vs control subjects with IDDM;

${ }^{\mathrm{b}} \mathrm{p}<0.05$, subjects with diabetic nephropathy vs both control groups;

${ }^{c} p<0.05$, subjects with diabetic nephropathy vs non-diabetic control subjects

\section{Results}

The three groups of subjects were similar with respect to age and sex (Table 1). However the diabetic control subjects had a significantly longer duration of diabetes than the subjects with diabetic nephropathy. Both groups of control subjects had a significantly lower body mass index than the subjects with diabetic kidney disease. As expected these subjects were significantly more likely to have clinical evidence of diabetic retinopathy and hypertension than control subjects. Diastolic blood pressure was similar in the two control groups and significantly lower than in the subjects with diabetic nephropathy. There was no significant difference between the systolic blood pressure of the two groups of diabetic subjects, though the normal control subjects had a significantly lower systolic blood pressure than the subjects with diabetic nephropathy.

The two groups of diabetic subjects had similar glomerular filtration rates, serum creatinine and $\mathrm{HbA}_{1 \mathrm{c}}$ (Table 2), though the serum creatinine was significantly lower in the non-diabetic control subjects compared to the subjects with diabetic nephropathy. Fasting serum triglycerides were significantly higher in the subjects with diabetic kidney disease compared to both of the control groups. In addition insulin dose per $\mathrm{kg}$, a surrogate for insulin resistance,
Table 2. Biochemical characteristics of subjects

\begin{tabular}{|c|c|c|c|}
\hline & $\begin{array}{l}\text { Normal } \\
\text { control } \\
\text { subjects } \\
(\mathrm{n}=18)\end{array}$ & $\begin{array}{l}\text { IDDM } \\
\text { control } \\
\text { subjects } \\
(\mathrm{n}=20)\end{array}$ & $\begin{array}{l}\text { Subjects with } \\
\text { IDDM and } \\
\text { nephropathy } \\
(n=18)\end{array}$ \\
\hline $\mathrm{HbA}_{1 \mathrm{c}}(\%)$ & - & $\begin{array}{l}7.5 \\
(7.0-8.0)\end{array}$ & $\begin{array}{l}8.5 \\
(7.6-9.4)\end{array}$ \\
\hline $\begin{array}{l}\text { Creatinine } \\
\left(\mu \mathrm{mol} \cdot 1^{-1}\right)\end{array}$ & $\begin{array}{l}81 \\
(72-98)\end{array}$ & $\begin{array}{l}86 \\
(67-109)\end{array}$ & $\begin{array}{l}90^{\mathrm{c}} \\
(67-116)\end{array}$ \\
\hline $\begin{array}{l}\text { Glomerular } \\
\text { filtration rate } \\
\left(\mathrm{ml} \cdot \min ^{-1} \cdot 1.73 \mathrm{~m}^{-2}\right)\end{array}$ & - & $\begin{array}{l}106 \\
(96-116)\end{array}$ & $\begin{array}{l}100 \\
(89-111)\end{array}$ \\
\hline $\begin{array}{l}\text { Cholesterol } \\
\left(\mathrm{mmol} \cdot \mathrm{l}^{-1}\right)\end{array}$ & $\begin{array}{l}5.0 \\
(4.6-5.4)\end{array}$ & $\begin{array}{l}5.1 \\
(4.6-5.6)\end{array}$ & $\begin{array}{l}6.0 \\
(5.4-6.6)\end{array}$ \\
\hline $\begin{array}{l}\text { Triglycerides } \\
\left(\mathrm{mmol} \cdot \mathrm{l}^{-1}\right)\end{array}$ & $\begin{array}{l}0.9 \\
(0.3-1.6)\end{array}$ & $\begin{array}{l}0.8 \\
(0.4-2.2)\end{array}$ & $\begin{array}{l}1.4^{\mathrm{b}} \\
(0.7-6.9)\end{array}$ \\
\hline $\begin{array}{l}\text { Urinary albumin } \\
\text { excretion rate } \\
\left(\mu \mathrm{g} \cdot \mathrm{min}^{-1}\right)\end{array}$ & $\begin{array}{l}3.8 \\
(2.4-10.7)\end{array}$ & $\begin{array}{l}4.6 \\
(2.6-15.7)\end{array}$ & $\begin{array}{l}92.8^{\mathrm{b}} \\
(29.0-3400)\end{array}$ \\
\hline $\begin{array}{l}\text { Insulin dose } \\
\left(\mathrm{IU} \cdot \mathrm{kg}^{-1}\right)\end{array}$ & - & $\begin{array}{l}0.63 \\
(0.55-0.72)\end{array}$ & $\begin{array}{l}0.83^{\mathrm{a}} \\
(0.73-0.93)\end{array}$ \\
\hline
\end{tabular}

Continuous variables described as mean (95\% confidence intervals).

Fasting triglycerides, urinary albumin excretion rate and serum creatinine described as median with range.

${ }^{a} p<0.05$, subjects with diabetic nephropathy vs control subjects with IDDM;

${ }^{\mathrm{b}} \mathrm{p}<0.05$, subjects with diabetic nephropathy vs both control groups;

${ }^{c} p<0.05$, subjects with diabetic nephropathy vs non-diabetic control subjects

was significantly higher in the subjects with diabetic nephropathy compared to the diabetic control subjects.

When assessed using the single point assay, median $\mathrm{V}_{140}$ was significantly lower in the normal control subjects compared to the subjects with diabetic kidney disease (Table 3 and Fig. 1 a). Although the median $\mathrm{V}_{140}$ was higher in these subjects compared to the diabetic control subjects this did not reach statistical significance.

When the kinetic parameters of Na-Li CT were considered (Table 3, Fig. $1 \mathrm{a}$, and b), $\mathrm{V}_{\max }$ was significantly higher in the subjects with diabetic nephropathy compared to both control groups. The Michaelis constant, $\mathrm{K}_{\mathrm{m}}(\mathrm{So})$, of all three groups was similar. $\mathrm{V}_{\mathrm{max}} / \mathrm{K}_{\mathrm{m}}$ ratio, reflecting ion association, was significantly higher among the subjects with diabetic kidney disease compared to both groups of control subjects.

The percentage reduction in $\mathrm{V}_{\max }$ after thiol group alkylation with NEM in subjects with diabetic nephropathy was $58(36-69 \%)$ but was significantly greater among the diabetic (65 (54-72\%)) and non-diabetic control subjects $(66(48-72 \%)), p<0.05)$. Thus the difference in $\mathrm{V}_{\max }$ between the subjects with diabetic nephropathy and the two control groups, observed in untreated erythrocytes, was enhanced. Thiol group alkylation had no significant effect on the Michaelis constant, $\mathrm{K}_{\mathrm{m}}(\mathrm{So})$, in the subjects with diabetic 
Table 3. Comparison of Na-Li CT activity, Na-Li CT kinetics and effect of thiol group alkylation in a sodium medium

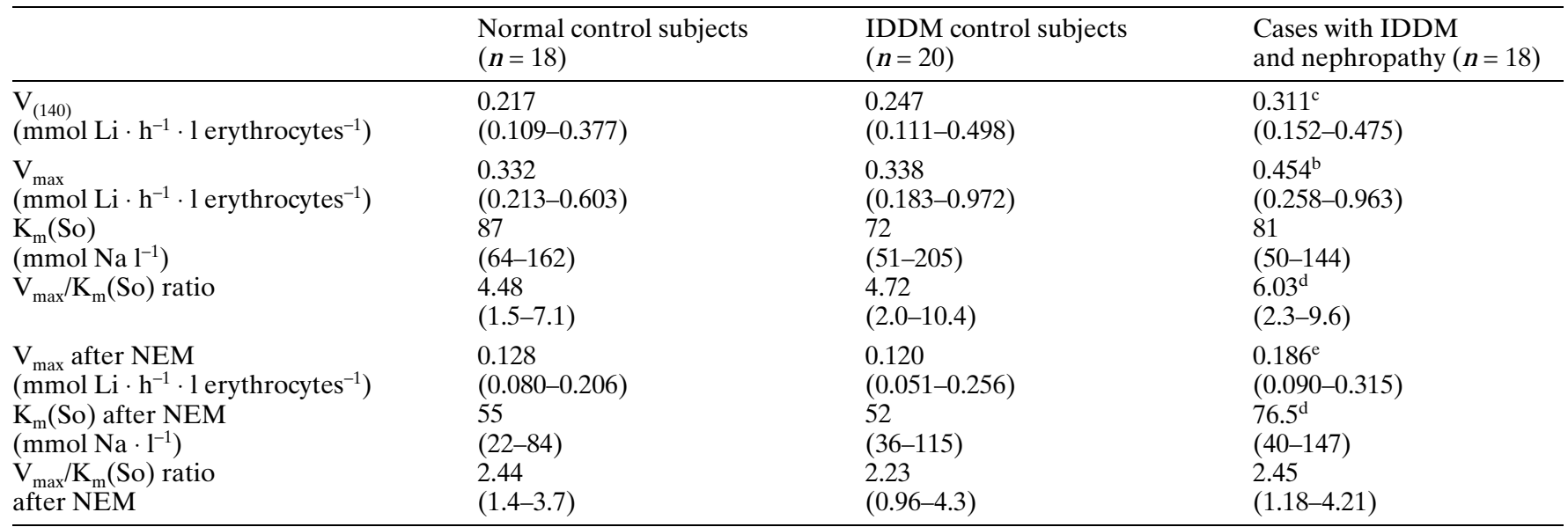

Variables described as median (range).

${ }^{a} p<0.05$, subjects with diabetic nephropathy vs control subjects with IDDM;

${ }^{b} p<0.05$, subjects with diabetic nephropathy vs both control groups;

nephropathy but resulted in a significant decrease in the control subjects with and without diabetes. These changes, after the addition of NEM, resulted in the abolition of differences in the $\mathrm{V}_{\max } / \mathrm{K}_{\mathrm{m}}$ ratio between groups, observed in untreated erythrocytes.

Although described as discrete variables these kinetic parameters can interact. We therefore plotted $\mathrm{V}_{\max }$ (after NEM) against $\mathrm{V}_{\max } / \mathrm{K}_{\mathrm{m}}($ So) ratio (untreated erythrocytes) in an attempt to improve discrimination between subjects with and without nephropathy, while taking into account potential interactions between the kinetic parameters (Fig.2). Using these parameters $78 \%$ of subjects with diabetic nephropathy were outside the 75th percentiles for both $\mathrm{V}_{\max }$ and $\mathrm{V}_{\max } / \mathrm{K}_{\mathrm{m}}$ ratio for the normal subjects. On the other hand only $20 \%$ of IDDM control subjects were outside the 75 th percentiles.

Among patients with diabetic nephropathy there was a significant correlation between log transformed $\mathrm{V}_{\text {max }}$ and $\log$ transformed serum triglycerides $(r=0.4$, $95 \%$ confidence limits $0.14-0.61)$. This relationship remained after thiol group blockade with NEM $(r=0.46,95 \%$ confidence intervals $0.21-0.65)$. No such relationship was detected among the diabetic or non-diabetic control subjects. In addition there was no statistical relationship between $\mathrm{V}_{\max }$ and $\mathrm{HbA}_{1 \mathrm{c}}$, nor was there any relationship between $\mathrm{V}_{\max } / \mathrm{K}_{\mathrm{m}}(\mathrm{So})$ ratio and serum triglycerides or $\mathrm{HbA}_{1 \mathrm{c}}$. Although subjects with both microalbuminuria and overt nephropathy were included there were no significant differences in Na-Li CT parameters between these groups. In addition there were no differences between subjects receiving antihypertensive treatment in general and angiotensin converting enzyme (ACE) inhibition in particular.
${ }^{c} p<0.05$, subjects with diabetic nephropathy vs non-diabetic control subjects;

${ }^{d} p<0.01$, subjects with diabetic nephropathy vs both control groups;

${ }^{\mathrm{e}} \mathrm{p}<0.0001$, subjects with diabetic nephropathy vs both control groups

\section{Discussion}

This kinetic analysis of Na-Li CT activity demonstrated a clear abnormality in the function of the transporter in subjects with diabetic nephropathy. The $\mathrm{V}_{\max } / \mathrm{K}_{\mathrm{m}}(\mathrm{So})$ ratio was greater in the subjects with diabetic nephropathy than in both control groups, suggesting that ion association with the Na-Li CT moiety is more rapid in the patients with diabetic kidney disease. This difference was independent of metabolic factors such as serum triglycerides or $\mathrm{HbA}_{1 \mathrm{c}} \cdot \mathrm{V}_{\max }$ was also higher in the subjects with diabetic nephropathy. Some but not all of this difference may be explained by a significant correlation between $\mathrm{V}_{\max }$ and triglyceride levels. However this relationship was only detected among the subjects with nephropathy suggesting that the hypertriglyceridaemia that has been well described in patients with diabetic nephropathy is part of the underlying membrane and metabolic abnormality rather than representing a confounding factor.

Despite the difference in kinetic parameters the standard assay of Na-Li CT $\left(\mathrm{V}_{140}\right)$ could not show a significant difference between the diabetic subjects with and without nephropathy. This finding using the $\mathrm{V}_{140}$ assay is similar to the findings of two previous studies $[15,16]$ but differs from the findings of several others [3-5]. However even studies that have reported significant differences in $V_{140}$ have found that groups of diabetic subjects with and without nephropathy demonstrate considerable overlap [14]. The variability of results obtained may in part reflect our relatively poor understanding of potential environmental confounders, problems with subject selection and assay interpretation. In previous work, including that 

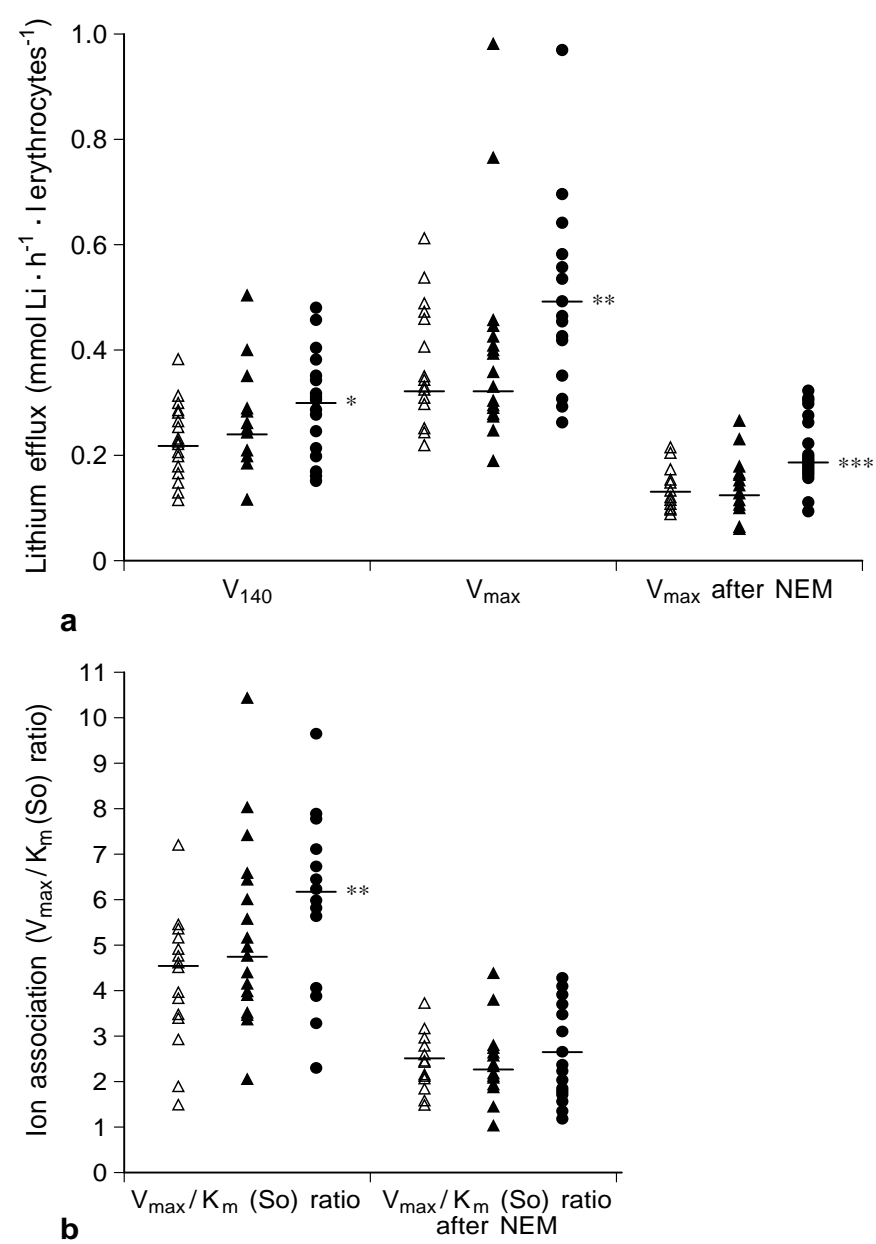

Fig. 1a. Scatter plot of $\mathrm{V}_{140}, \mathrm{~V}_{\max }$ and $\mathrm{V}_{\max }$ after NEM in nondiabetic control subjects $(\triangle)$, normoalbuminuric IDDM control subjects $(\mathbf{\Delta})$ and IDDM patients with nephropathy $(\mathbf{O})$. Median value, —. * $p<0.05$, subjects with nephropathy vs non-diabetic control subjects; $* * p<0.05$, subjects with nephropathy vs both control groups; $* * * p<0.0001$, subjects with nephropathy vs both control groups. b Scatter plot of $\mathrm{V}_{\max } /$ $\mathrm{K}_{\mathrm{m}}(\mathrm{So})$ ratio before and after NEM treatment in non-diabetic control subjects, normoalbuminuric IDDM control subjects and IDDM patients with nephropathy. Median value, $* * p<0.05$, subjects with nephropathy vs both control groups

of our own group [6], diabetic subjects with end-stage renal disease and control subjects of relatively short duration have been included. In the present study control subjects with IDDM were selected to have a duration of diabetes of at least 20 years, to ensure that they were unlikely to develop raised albumin excretion rates in the future. Subjects with raised creatinine (greater than $150 \mu \mathrm{mol} \cdot \mathrm{l}^{-1}$ ) were excluded to avoid confounding effects of uraemia on Na-Li CT activity, and subjects were similar with respect to glomerular filtration rate and $\mathrm{HbA}_{1 \mathrm{c}}$. In our previous report of Na-Li CT kinetics [6] $\mathrm{V}_{\max }$ and $\mathrm{K}_{\mathrm{m}}$ (So) in subjects with diabetic nephropathy and normal serum creatinine were very similar to the present study. In addition $\mathrm{V}_{\max } / \mathrm{K}_{\mathrm{m}}(\mathrm{So})$ ratio values, calculated in retrospect, are similar to the findings in the present

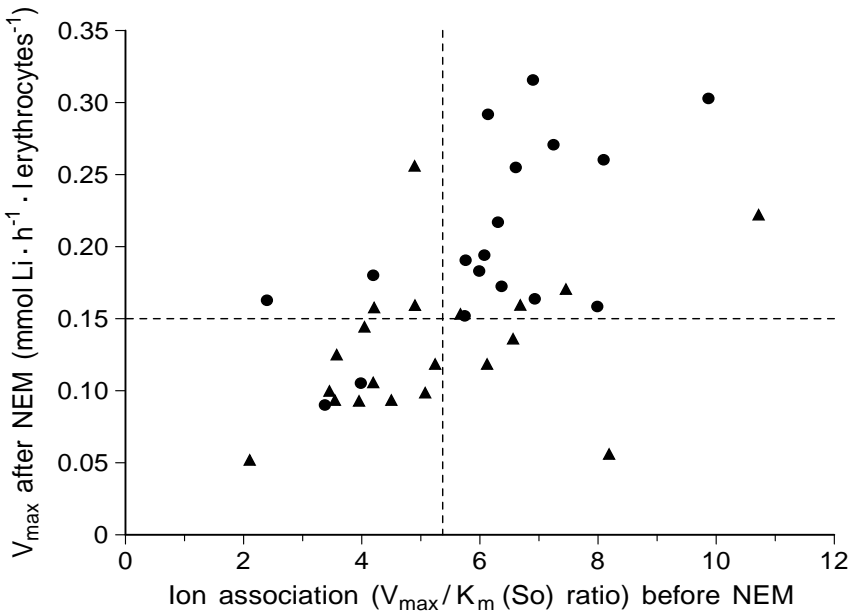

Fig. 2. Discrimination of patients with diabetic nephropathy (O) from diabetic control subjects ( $\boldsymbol{\Delta}$ ) using $\mathrm{V}_{\max }$ after NEM and $\mathrm{V}_{\max } / \mathrm{K}_{\mathrm{m}}(\mathrm{So})$ ratio before NEM treatment. 75 th percentile of normal controls, ----

study. The higher $\mathrm{V}_{\max }$ values in the normal control subjects in the previous study were a result of subject selection and would confound the use of $\mathrm{K}_{\mathrm{m}}(\mathrm{So})$ alone as an index of ion affinity.

Probing for the effect of thiol group modulation on $\mathrm{Na}-\mathrm{Li} \mathrm{CT}$ kinetics revealed further abnormalities in the patients with diabetic nephropathy. Thiol group alkylation with NEM abolished the $\mathrm{V}_{\mathrm{max}} / \mathrm{K}_{\mathrm{m}}($ So $)$ ratio differences between subjects with diabetic nephropathy and both control groups. This kinetic behaviour of Na-Li CT is very similar to that reported in essential hypertension [12]. An inherited abnormality in key thiol proteins may therefore represent the defect that underlies cell membrane abnormalities in both essential hypertension and diabetic nephropathy.

Alkylation with NEM of the unique thiol group that modulates $\mathrm{V}_{\max }$, and whose reactivity is dependent on sodium (or lithium), caused a proportionately smaller decrease in $\mathrm{V}_{\max }$ in the subjects with diabetic kidney disease, enhancing the differences in $\mathrm{V}_{\max }$ between the subjects with nephropathy and control subjects. Although thiol groups can modulate $\mathrm{V}_{\text {max }}$, some of the increased $\mathrm{V}_{\text {max }}$ activity in subjects with diabetic nephropathy may be ascribed to abnormal metabolic environment as well as a possible inherited defect in the function of a key protein.

The findings of this study together with previous studies suggest that the traditional Na-Li CT assay cannot fully describe the underlying abnormality and is not useful at the individual level. The kinetic parameters, $\mathrm{V}_{\max }$ and $\mathrm{V}_{\max } / \mathrm{K}_{\mathrm{m}}$ ratio also demonstrate considerable overlap, even though clear statistical differences have been demonstrated. The kinetic parameters, although described as discrete variables, can interact: for example if $\mathrm{V}_{\max }$ is raised because of increased transporter turnover then $\mathrm{K}_{\mathrm{m}}(\mathrm{So})$ will increase with no change in ion affinity. However if 
$\mathrm{V}_{\max }$ is raised because of increased number of transporters, $\mathrm{V}_{\max } / \mathrm{K}_{\mathrm{m}}(\mathrm{So})$ ratio will be increased without a real change in transporter affinity for cations. It is reasonable therefore to investigate the use of two kinetic parameters together to improve the ability of $\mathrm{Na}-\mathrm{Li} \mathrm{CT}$ to discriminate between individuals with and without diabetic nephropathy.

The clearest discrimination between subjects with nephropathy and control subjects with IDDM was obtained using $\mathrm{V}_{\max } / \mathrm{K}_{\mathrm{m}}(\mathrm{So})$ ratio and $\mathrm{V}_{\max }$ after NEM when $78 \%$ of subjects with diabetic nephropathy were outside the 75 th percentiles for the normal subjects. On the other hand only $20 \%$ of IDDM control subjects were outside the 75 th percentiles, as would be expected in a group with "normal characteristics". However there were individuals both with and without nephropathy that had Na-Li CT characteristics very different to the rest of their group. There may be two reasons for this observation. Firstly abnormal Na-Li CT may indicate increased susceptibility to the development of diabetic nephropathy, as in essential hypertension, but is not sufficient if diabetes control is good. Secondly diabetic nephropathy is itself heterogeneous. Some patients progress very rapidly from microalbuminuria through to overt nephropathy and on to end-stage renal disease with coexistent hypertension, cardiovascular disease and retinopathy. Others have proteinuria for many years but progress very slowly to end-stage renal disease and develop less severe micro and macrovascular complications. One of the two subjects with diabetic nephropathy and apparently normal Na-Li CT kinetics falls into the latter category.

At the practical level, the findings of the present study would allow us to identify around $80 \%$ of individuals with nephropathy. The findings of this crosssectional study require confirmation in a prospective study. If confirmed and applied to a cohort of subjects with newly diagnosed IDDM, preventative treatment such as intensified glycaemic control and/or early use of ACE inhibitors could be better targeted on those at the greatest risk of nephropathy. Of course using these criteria some individuals will be over treated. At present however all patients with newly diagnosed IDDM are potentially at equal risk of complications. It could be argued that the $70 \%$ who will never go on to develop diabetic kidney disease are currently treated too aggressively though good glycaemic control is still important in the prevention of other complications, most notably retinopathy.

This study confirms that Na-Li CT is best assessed by measuring kinetic parameters rather than using a single point assay. Na-Li CT is modulated by key protein thiol groups which appear to be responsible for important differences in Na-Li CT kinetics, especially ion binding, observed in subjects with diabetic nephropathy. As well as helping to define the underlying cell membrane defect this information can be used to improve the ability of Na-Li CT to discriminate between subjects with diabetic nephropathy and diabetic control subjects.

A cknowledgements. The authors are indebted to Ms. V. Mott and Ms. A. Taylor for invaluable technical assistance. This work was partly funded by The Northern Counties Kidney Research Fund. S. C. Jones is a recipient of a Northern Region Research Training Fellowship.

\section{References}

1. Quinn M, Angelico MC, Warram JH, Krolewski AS (1996) Familial factors determine the development of diabetic nephropathy in patients with IDDM. Diabetologia 39: 940-945

2. The Diabetes Control and Complications (DCCT) Research Group (1995) Effect of intensive therapy on the development and progression of diabetic nephropathy in the Diabetes Control and Complications Trial. Kidney Int 47: 1703-1720

3. Krolewski AS, Canessa M, Warram JH et al. (1988) Predisposition to hypertension and susceptibility to renal disease in insulin-dependent diabetes mellitus. N Engl J Med 318: 140-145

4. Mangili R, Bending JJ, Scott G, Li LK, Gupta A, Viberti GC (1988) Increased sodium-lithium countertransport activity in red cells of patients with insulin-dependent diabetes and nephropathy. N Engl J Med 318: 146-150

5. Jones SL, Trevisan R, Tariq T et al. (1990) Sodium-lithium countertransport activity is increased in microalbuminuric diabetics. Hypertension 19: 570-575

6. Rutherford PA, Thomas TH, Carr SJ, Taylor R, Wilkinson R (1992) Changes in erythrocyte sodium-lithium countertransport kinetics in diabetic nephropathy. Clin Sci 82: 301-307

7. Hasstedt SJ, Wu LL, Ash KO, Kuida H, Williams R (1988) Hypertension and sodium-lithium countertransport in Utah pedigrees: evidence for major locus inheritance. Am J Hum Genet 43:14-22

8. Hannaert PA, Garay RP (1986) A kinetic analysis of $\mathrm{Na}-\mathrm{Li}$ countertransport in human red blood cells. J Gen Physiol 87: 353-68

9. Becker BF, Duhm J (1979) Studies of lithium transport across the red cell membrane. VI Properties of a sulphydryl group involved in ouabain-resistant $\mathrm{Na}-\mathrm{Li}$ and $(\mathrm{Na}-\mathrm{Na}$ ) exchange in human and bovine erythrocytes. J Membrane Biol 51: 263-286

10. Levy R, Livine A (1984) Erythrocyte Li-Na countertransport system. Inhibition by N-ethylmaleimide probes for a conformational change of the transport system. Biochim Biophys Acta 777: $157-166$

11. Thomas TH, West IC, Wilkinson R (1995) Modification of erythrocyte $\mathrm{Na}+/ \mathrm{Li}+$ countertransport kinetics by two types of thiol group. Biochim Biophys Acta 1235: 317-322

12. Thomas TH, Rutherford PA, West IC, Wilkinson R (1995) Sulphydryl group control of sodium-lithium countertransport kinetics: a membrane protein control abnormality in essential hypertension. Eur J Clin Invest 25: 235-240

13. Chantler C, Garnett ES, Parsons V, Veall N (1969) Glomerular filtration rate measurement in man by the single injection method using 51 Cr EDTA. Clin Sci 37: 811-803

14. Rutherford PA, Thomas TH, Wilkinson R (1992) Erythrocyte sodium-lithium countertransport: clinically useful, pathophysiologically instructive or just phenomenology? Clin Sci 82: 341-352

15. Elving LD, Wetzels JFM, DeNobel E, Berden JHM (1992) Erythrocyte sodium-lithium countertransport is not different in type 1 (insulin-dependent) diabetic patients with and without diabetic nephropathy. Diabetologia 34: 126-128

16. Jensen JS, Mathiesen ER, Nørgaard K et al. (1990) Increased blood pressure and erythrocyte sodium-lithium countertransport activity are not inherited in diabetic nephropathy. Diabetologia 33: 619-624 